\title{
READERS
Insight
}

Journal of Management Info (JMI)

ISSN:2313-3376

www.readersinsight.net/jmi

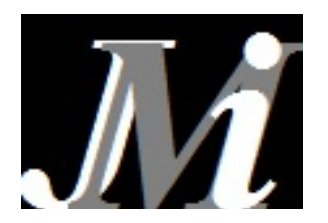

\section{Effects of perceived stressors and psychiatric morbidity on academic performance of university students}

\author{
Aftab Alam Khan ${ }^{1 *}$, Abid Sultan², Farzand Ali Jan³ \\ ${ }^{1}$ Ayub Medical College, Abbotabad, Pakistan \\ 2,3 COMSATS Institute of Information Technology, Attock, Pakistan \\ * Corresponding author: aftab_7710@hotmail.com
}

\begin{abstract}
The current study aims at examining the effects of perceived stressors and psychiatric morbidity on the students' academic performance by taking COMSATS Institute of Information Technology, Attock as case study. Using a cross sectional design, the data was collected on four stressors, i.e. Workload, Emotional \& Interpersonal Demands and three types of psychiatric morbidities, i.e. Depression, Anxiety \& Social Dysfunction from 379 students. The Job-Demand-Resource Model (JD-R) model was used as theoretical base for formulating research framework. The existing literature states that level of students' performance varies with the level of perceived stress and symptoms of mental illness. The findings of current study are in concurrence with findings of previous research. It has been found that perceived stressors and symptoms of mental illness were negatively related with students' academic performance. The results of this study will be helpful to students, teacher and to administration of University for taking conducive steps to minimize the impacts of perceived stress on the students' academic performance.
\end{abstract}

\section{ARTICLE INFORMATION}

\author{
Received: 25 March 2017 \\ Revised: $\quad 25$ April 2017 \\ Accepted: 25 May 2017
}

DOI:

http://dx.doi.org//10.31580/jmi.v4i1.29

\section{Introduction}

Higher Education Institutions are strategic assets of any country as they provide intellectual capital and meet the technological and personnel related requirement (Burchi, 2006; Goldstein \& Drucker, 2006). Higher Education Institutions also act as a source of alleviation of the unemployment rate by impacting quality education and skills, which can later on help in attaining jobs (Angang \& Xin, 2006). Developing economies like Pakistan relied on systems of its higher education to produce the talent for its workforce and to develop the intellectual foundation for the growth of new ideas and products (Burk, 2011). Higher Education Institutions are evaluated against world standards in regard to quality of education, values, costs and services (Hazelkorn, 2011). Such standards are sometimes difficult to comply, resultantly employees working in Higher Education Institutions experience pressure. This pressure is in shape of increase workload, time constraints, multiple roles and task complexities. Such pressure is ultimately shifted to the students, who are expected to meet the quality requirements (Alexander, 2000).

Previous studies for e.g. (Hamaideh, 2009; Khawaja, 2008; Kiselica, Baker, Thomas, \& Reedy, 1994) identified certain factors like work overload, course requirements, financial issues, time management; role ambiguity, interactions with peers and faculty, social activities, adjustment to new campus environment and lack of support networks are the main stressors, which causes physical and psychological health problems and ultimately impede the students' academic performance. Apart from this other authors like Hartley Michael (2011) and Adams et al., (2008) found that stress and mental health problems impedes the academic performance of approximately a third of academic institute students. Stress can also cause physical sickness, insomnia, eating disorders, anxiety and depression. Such studies strongly suggested that the problem of stress among students should be further investigated because stress and certain psychiatric morbidities have become an emerging issue in world of academia. It is therefore important to study these factors, so that their effect could be comprehended and possible solution could be formulated.

Keeping in view this issue, the current study has empirically studied the effect of perceived stressors and psychiatric morbidity on the academic performance of university students. In this regard COMSATS Institute of Information Technology, Attock was selected as special case because the Attock campus of COMSATS Institute of Information Technology is comparatively new born as it has recently completed its ten years of establishment. That is why this campus is still experiencing different types of problems. In this regard data was collected from 300 students through online questionnaire. The results of current study show that both perceived stressors and psychiatric morbidity had negative effect on the academic performance of students. It is therefore concluded that students' stress is a recognized workplace problem. It requires proactive actions as solution to be taken both at individual and institutional levels.

Keeping in view the above discussion, the current study has investigated following research question:

1. What is the relationship between prevalent stressors and psychiatric morbidities?

2. What is the relationship between prevalent stressors and psychiatric morbidities and students' academic performance?

These questions will be answered by testing the following hypotheses: 1. Psychiatric morbidities will be positively related with perceived stressors. 
2. The prevalent stressors will be negatively related with students' academic performance.

3. The perceived psychiatric morbidities will be will be negatively related with students' academic performance.

\section{Methodology}

This section has discussed the methodology of current study.

\section{Research design}

A cross sectional research design was selected. The cross section study is preferred over longitudinal studies because it is time and cost effective, where it provides snap shot results (Cooper \& Schindler, 2010)

\section{Population and sampling}

The Population of current study consists of students studying in three departments of COMSATS Institute of Information Technology, Attock. The details are given in Table 1.

Table 1: Population Distribution

\begin{tabular}{|c|c|c|}
\hline Departments & $\begin{array}{l}\text { Population } \\
\text { Male (N) }\end{array}$ & Female (N) \\
\hline Computer Science & 389 & 125 \\
\hline Management Science & 150 & 90 \\
\hline Electrical Engineering & 207 & 32 \\
\hline Mathematics & 37 & 112 \\
\hline Total & 783 & 359 \\
\hline
\end{tabular}

It was not practically possible to collect data from all students, therefore two stages sampling technique was used. At first stage stratification was done on basis of gender and department. At second stage systematic sampling was used to select final sample. Two strata were made on basis of gender, i.e. Male and female. Four strata were made on the basis of departments, i.e. Management sciences, Computer Sciences, Electrical Engineering and Mathematics. Finally, systematic sampling technique was applied by selecting every third respondent from each stratum. The detail is given in Table 2 .

Table 2: Sampling Distribution

\begin{tabular}{lll}
\hline Departments & \multicolumn{2}{l}{ Population } \\
Male (n) & Female (n) \\
\hline Computer Science & 130 & 41 \\
Management Science & 50 & 30 \\
Electrical Engineering & 69 & 10 \\
Mathematics & 12 & 37 \\
Total & 261 & 118 \\
\hline
\end{tabular}

\section{Data collection and analysis}

Data was collected through an online self administered questionnaire, which consisted of 49 items as shown in Table 3.

Table 3: The detail of questionnaire items

\begin{tabular}{lll}
\hline Variable & $\begin{array}{l}\text { Scale } \\
\text { source }\end{array}$ & No of Items \\
\hline Demographic & --- & 07 \\
\hline Stressors & & \\
\hline $\begin{array}{l}\text { (Work Load, Interpersonal } \\
\text { Demands, Role Conflict \& }\end{array}$ & Rao (2013) & 15 \\
$\begin{array}{l}\text { Ambiguity, Physical Workplace) } \\
\text { Performance }\end{array}$ & \\
$\begin{array}{l}\text { (Environment Mobility, Learning } \\
\text { Skills, Self-Determination Skills, } \\
\text { Social Skills) }\end{array}$ & $\begin{array}{l}\text { Functional } \\
\text { Performance }\end{array}$ & \\
Psychiatric Morbidity & $\begin{array}{l}\text { Rating Scale } \\
(2013)\end{array}$ & \\
(Anxiety, Depression, Social & $\begin{array}{l}\text { Goldberg \& } \\
\text { Dysfunction) }\end{array}$ & 12 \\
Wotal & $\begin{array}{l}\text { Williams } \\
(1988)\end{array}$ & \\
& &
\end{tabular}

The online questionnaire was circulated among students and their responses were online reordered. The data collation process was completed within two months. The collected data was initially screened for missing values and normality analysis. It was found that 79 questionnaires had missing values and normality issues, therefore such cases were deleted. The data was analyzed by using descriptive and inferential statistics. In this regard frequency tables were used to present demographic data and hierarchical multiple regression analysis was used to check the relationship between perceived stressors, psychiatric morbidity and academic performance of students.

\section{Results}

This section has discussed the results of study. The demographic data shows that majority of respondents were male $(64.70 \%)$, unmarried $(67.30 \%), 17$ to 22 years old $(71.70 \%)$ with at least intermediate level education $(63.66 \%)$ as clear from Table 4 . The results further show that department of Management Science $(28.30 \%)$ and Electrical Engineering (31.70\%) had majority of respondents. Such results mean that the respondents are in their early adult hood transition age, which is characterized by adoption to changes of life. Such age is more vulnerable to mental health problems as it is immature and transition age (Grant \& Potenza, 2010).

Table 4: Demographic Profile of Respondents

\begin{tabular}{llll}
\hline & Variables & Number & $\begin{array}{l}\text { Percentage } \\
\text { (\%) }\end{array}$ \\
\hline \multirow{2}{*}{ Gender } & Male & 194 & 64.7 \\
& Female & 106 & 35.3 \\
& Age17 to 19 years & 120 & 40.0 \\
Age & 20 to 22 years & 95 & 31.7 \\
& 23 to 24 years & 60 & 20.0 \\
Marital & Above 25 years & 25 & 8.30 \\
Status & Married & 98 & 32.70 \\
Educational & Unmarried & 202 & 67.30 \\
Level & Intermediate & 191 & 63.66 \\
& Masters & 109 & 36.34 \\
& Management & 85 & 28.30 \\
Departments & Science & 55 & 18.33 \\
& Computer Science & 55 & 31.70 \\
& Electrical & 95 & 21.66 \\
\hline
\end{tabular}

The multivariate analysis shows that the all types of stressors and symptoms of mental illness were positively related with each other. However, they were negatively related with academic performance of students. Table 5 shows that perceived stressors are positively related with symptoms of anxiety, depression and social dysfunction, where all stressors have cumulatively explained $15 \%$ of variance in symptoms of mental illness. Therefore, the first hypothesis has been accepted.

Table 5: Regression Analysis Results (Hypothesis 01)

\begin{tabular}{llll}
\hline & Anxiety & Depression & $\begin{array}{l}\text { Social } \\
\text { Dysfunction }\end{array}$ \\
\hline Step 01 & $\beta$ & $\beta$ & $\beta$ \\
Gender & 0.036 & 0.022 & 0.012 \\
Age & 0.032 & 0.009 & 0.019 \\
Marital Status & 0.081 & 0.087 & 0.017 \\
Department & 0.048 & 0.045 & 0.025 \\
Step 02 & & & \\
Gender & 0.036 & 0.024 & 0.016 \\
Age & 0.024 & 0.007 & 0.014 \\
Marital Status & 0.076 & 0.081 & 0.022 \\
Department & 0.027 & 0.045 & 0.003 \\
Workload & $0.119^{* *}$ & $0.127^{* *}$ & $0.231^{* *}$ \\
Interpersonal & $0.125^{\star *}$ & $0.173^{* *}$ & $0.121^{* *}$ \\
Demands & & & \\
Emotional & $0.111^{* *}$ & $0.235^{* *}$ & $0.147^{* *}$ \\
Demands & 0.019 & 0.025 & 0.099 \\
R2 Step 01 & $0.125^{* *}$ & $0.178^{* *}$ & $0.185^{* *}$ \\
R2 Step 02 & 0.987 & 0.887 & 0.784 \\
F Step 01 & $12.36^{* *}$ & $10.72^{* *}$ & $8.66^{\star *}$ \\
F Step 02 & & &
\end{tabular}


illnesses like depression and anxiety were negatively affecting the

Table 6 shows that that perceived stressors are negatively related with academic performance, where workload, interpersonal demands and emotional demands have explained $23 \%$ variance in the academic performance of students. The Standardized $\beta$ Coefficients for workload is $\left(-0.323^{* *}\right)$, where as for interpersonal demands it is $\left(-0.187^{* *}\right)$ and for emotional demands $(-0.122 * *)$. This means that perceived stressors are negatively related with academic performance. Thus the second hypothesis has been accepted.

Table 6: Regression Analysis Results (Hypothesis 02)

\begin{tabular}{lll}
\hline & \multicolumn{2}{l}{ Academic Performance } \\
\hline Step 01 & $\mathrm{B}^{\mathrm{a}}$ & $\mathrm{t}$ \\
Gender & 0.012 & -0.216 \\
Age & 0.012 & -0.214 \\
Marital Status & 0.103 & 1.780 \\
Department & 0.123 & 1.023 \\
STEP 02 & & \\
Gender & 0.008 & -0.161 \\
Age & 0.022 & -0.435 \\
Marital Status & 0.074 & 1.458 \\
Department & 0.015 & 0.025 \\
Workload & $-0.323^{* *}$ & -5.620 \\
Interpersonal Demands & $-0.187^{\star *}$ & -3.181 \\
Emotional Demands & $-0.122^{* *}$ & -2.282 \\
$\Delta \mathrm{R}^{2}$ Step 01 & 0.011 & \\
$\Delta \mathrm{R}^{2}$ Step 02 & $0.238^{* *}$ & \\
$\Delta \mathrm{F}$ Step 01 & 1.101 & \\
$\Delta \mathrm{F}$ Step 02 & $0.235^{\star *}$ & \\
a= Standardized $\beta$ Coefficients; ${ }^{*} \mathrm{p}<0.05 ;{ }^{* *} \mathrm{p}<0.001$ &
\end{tabular}

Table 7 shows that symptoms of mental illness are negatively related with academic performance of students. The symptoms of mental illness have explained $32 \%$ of variance in academic performance of students. The Standardized $\beta$ Coefficients for Anxiety is $\left(-0.148^{* *}\right)$, where as for depression it is $\left(-0.121^{* *}\right)$ and for social dysfunction ($0.222 * *)$. This means that symptoms of mental illness are negatively related with academic performance of students. Thus the third hypothesis has been accepted.

Table 7: Regression Analysis Results (Hypothesis 03)

\begin{tabular}{lll} 
& \multicolumn{2}{l}{ Academic Performance } \\
\hline Step 01 & $\mathrm{B}^{\mathrm{a}}$ & $\mathrm{t}$ \\
Gender & 0.088 & -0.221 \\
Age & 0.022 & -0.230 \\
Marital Status & 0.025 & 1.298 \\
Department & 0.014 & 1.585 \\
STEP 02 & & \\
Gender & 0.008 & -0.258 \\
Age & 0.023 & -0.154 \\
Marital Status & 0.055 & 2.365 \\
Department & 0.024 & 0.257 \\
Anxiety & $-0.148^{* *}$ & 0.235 \\
Depression & $-0.121^{* *}$ & -3.32 \\
Social Dysfunction & $-0.222^{* *}$ & -1.2554 \\
$\Delta \mathrm{R}^{2}$ Step 01 & 0.012 & \\
$\Delta \mathrm{R}^{2}$ Step 02 & $0.221^{* *}$ & \\
$\Delta \mathrm{F}$ Step 01 & 1.244 & \\
$\Delta \mathrm{F}$ Step 02 & $0.325^{* *}$ & \\
$\mathrm{a}=$ Standardized $\beta$ Coefficients; ${ }^{*} \mathrm{p}<0.05 ;{ }^{* *}$ & $\mathrm{p}<0.001$ &
\end{tabular}

\section{Discussion}

The current study aims at examining the effects of perceived stressors and psychiatric morbidity on the students' academic performance by taking COMSATS Institute of Information Technology, Attock as case study. The results show that both perceived stressors and psychiatric morbidity were negatively affecting the academic performance of students in such a way that the perceived stressors and psychiatric morbidity were positively related with each other. That is why their effect on academic performance was combined. The results of current study are in aligned with findings of previous studies. Eisenberg, Golberstein, \& Hunt (2009) found that mental
Graduate Average Point and academic performance of university students in Michigan state of America. Similarly, McLeod, Uemura, \& Rohrman (2012) found that psychiatric morbidities like attention problems, depression, delinquency, and substance use were negatively related with academic performance of American students. In another study Sreeramareddy et al., (2007) found that psychological morbidity, stressors and issues of quality of life had significantly negative effect on learning and academic performance of medical students in Nepal. The findings of these studies confirm that perceived stressors and resultant mental illness have significantly negative effect on the learning, academic performance and overall development of university students.

\section{Conclusion}

University students are valuable asserts of any country. The environment of modern universities has created different demands, which have made the life of student difficult. Students have to fulfill both academic and non academic requirements as a result of which they are subjected to different types of stressors. Such stressors ultimately develop some mental illness as a result of which the academic and non academic performance of students is negatively affected. The findings of current study have supported this fact. The findings revealed that both perceived stressors and psychiatric morbidities were negatively related with students' academic performance. It is therefore concluded that perceived stressors and psychiatric morbidities are recognized work place hazards and they have devastating effects on the academic performance of universities students. Furthermore, it has been concluded that perceived stressors and psychiatric morbidities require proper management both at individual and institutional levels. At individual level the students should get enough awareness about the causes and symptoms of mental illness. On other side at institutional level the academic staff members and administration of university should provide a favorable working environment to the students and their problems should be properly addressed and solved, so that students could be saved from the devastating effects of mental illness. In this way we can give mentally fit and academically brilliant student to society.

\section{References}

Alexander, F. K. (2000). The changing face of accountability: Monitoring and assessing institutional performance in higher education. Journal of Higher Education, 411-431.

Angang, H., \& Xin, S. (2006). Urban Unemployment in China: A backgournd analysis. In G. Lee \& M. Warner (Eds.), Unemployment in China: Economy, Human Resources and Labour Markets: Routledge.

Burchi, F. (2006). Identifying the Role of Education in Socio-Economic Development. Paper presented at the Proceedings of the Conference on Human and Economic Resources, Izmir University of Economics.

Burk, A. (2011). In your opinion, what should the purpose of education be? , from

http://www.ted.com/conversations/7491/in_your_opinion_what_should_t. html

Cooper, D., \& Schindler, P. (2010). Business Research Methods: McGraw-Hill Education.

Eisenberg, D., Golberstein, E., \& Hunt, J. B. (2009). Mental health and academic success in college. The BE Journal of Economic Analysis \& Policy, 9(1).

Goldberg, D., \& Williams, P. (1988). A User's Guide to the General Health Questionnaire: NFER-NELSON.

Goldstein, H., \& Drucker, J. (2006). The Economic Development Impacts of Universities on Regions: Do Size and Distance Matter? Economic Development Quarterly, 20(1), 22-43.

Grant, J. E., \& Potenza, M. N. (2010). Young Adult Mental Health: Oxford University Press.

Hamaideh, S. H. (2009). Stressors and reactions to stressors among university students. International journal of social psychiatry.

Hazelkorn, E. (2011). Rankings and the Reshaping of Higher Education: the Battle for World Wide Excellence.

Khawaja, N. G. a. D., Jennifer. (2008). A comparison of International

and Domestic Tertiary Students in Australia. Australian Journal of Guidance \& 
Counselling, 18(1), 30-46.

Kiselica, M. S., Baker, S. B., Thomas, R. N., \& Reedy, S. (1994). Effects of stress inoculation training on anxiety, stress, and academic performance among adolescents. Journal of Counseling Psychology, 41(3), 335.

McLeod, J. D., Uemura, R., \& Rohrman, S. (2012). Adolescent mental health, behavior problems, and academic achievement. Journal of health and social behavior, 0022146512462888 .
Rao, B. (2013). A study of academic stress and adjustment styles of teacher trainees. Unpublished PhD, Acharya Nagarjuna University.

Sreeramareddy, C. T., Shankar, P. R., Binu, V., Mukhopadhyay, C., Ray, B., \&

Menezes, R. G. (2007). Psychological morbidity, sources of stress and coping strategies among undergraduate medical students of Nepal. BMC Medical education, 7(1), 26 